\title{
Hearing Imparied Students' Attitudes Towards Physical Education and Sports
}

\author{
İbrahim Dalbudak ${ }^{1}$, ŞıMMehmet Yiğit ${ }^{2}$ \\ ${ }^{1}$ Isparta University of Applied Sciences, Turkey \\ ${ }^{2}$ Tekirdağ University of Namık Kemal, Turkey \\ Correspondence: İbrahim Dalbudak, Isparta University of Applied Sciences, Turkey.
}

Received: May 8, 2019 Accepted: May 28, $2019 \quad$ Online Published: July 1, 2019

doi:10.11114/jets.v7i9.4255 URL: https://doi.org/10.11114/jets.v7i9.4255

\begin{abstract}
In this study, it was aimed to determine the attitudes and opinions of hearing impaired primary school, high school, and university students towards physical education and sports lesson according to various variables.

To the study, a total of 136 students (50 females and 86 males) with hearing-impairment, who are participating physical education and sports lesson in provinces of İzmir and Muğla between 2017-2018 education year, voluntarily participated.

In the study, 2-part questionnaires were applied to the students. In the first part demographic features, and in the second part "Physical Education and Sports Attitude Scale" consisting of 12 positive and 12 negative items, a total of 24, which was developed by Demirhan and Altay (2001) to measure the attitudes of the students, were used. The Cronbach Alpha reliability coefficient was calculated as 0.93 ; and validity coefficient of the scale as 0.83 . In the analysis of the data; frequency, and percentage distributions were used and the relationship between physical education and sports attitude scores were analyzed with correlation analysis. The t-test was used to determine the difference according to gender, sporting status, and disability status in the analyses about physical education and sports attitude scores. Besides, one-way variance analysis (ANOVA) was used to determine the difference according to educational status, branches of sports, and level of income. The obtained data was recorded by using a programme called SPSS 22.00 in silico.

In this study, attitude scale scores of the physical education and sports showed a significant difference according to gender $(p<0,05)$. Males showed a better attitude than females. It does not show a difference according to education status ( $p>, 05)$. The average scores of the primary school, high school, and university students were close to each other. It showed a difference according to hearing impaired students' sporting status ( $p>, 05)$. No significant difference was found according to students' branches of sports $(\mathrm{p}>, 05)$. There was no significant difference according to doing individual and team sports. It was stated that there was a significant difference according to students' level of income $(\mathrm{p}<0,05)$; it showed that there was a significant difference between 500-1000 and 1000-2000, and 500-1000 and over 2000. No significant difference was found according to students' disability status ( $p>, 05)$. It shows difference according to students' having congenital or afterward disability.

According to the results of the study the participation of hearing-impaired students in physical education and sports activities; show that they qualify their leisure time doing sports and exercises, physical education and sports will provide significant benefits in my life. Allocating an important time to physical education and sports activities, they create awareness in the community, representing their country in Paralympic games show that they show a positive attitude towards physical education and sports.
\end{abstract}

Keywords: hearing impaired, physical education and sports, attitude

\section{Introduction}

"Attitude" as a word was first used by Herbert Spencer in 1862. Spencer used attitude to express an individual's mental status. Later in 1888, Lange reviewed attitude as a concept and analyzed. Although there are significant differences among the definitions used in today's world about attitude; he made a close definition to these definitions. Afterward, the attitude has become a popular topic which is researched and discussed by psychologists and sociologists. Moreover, such researches and discussion have been claimed to pioneer to arise of the discipline of social psychology (Güllü, 2009). 
Many definitions were made about attitude. According to Safrit and Wood (1995), these definitions a special feeling towards a situation, a person, or an activity. According to Ertürk (1998), attitudes can be different objects, hints, abilities, reinforcements, and materials in accomplishing related objectives about interests, abilities, and information. According to Tezbaşaran (1997); it is the tendency to react positively or negatively to a particular object, situation, institution, concept or other people. In this context, attitudes can be of varying degrees from the most positive to the most negative. Negative attitudes show itself against movements such as to have a negative belief in the object or ideas, to reject it or to dislike it. Positive attitudes can show itself as to have a positive belief in objects or ideas, to adopt and love it (Demirhan and Altay, 2001).

Students may develop positive or negative attitudes about physical education and sports course. The positive attitudes of the students towards physical education and sports course can be used to ensure the efficient processing of the course activities, to facilitate the achievement of specific and general objectives of the course, or to enable students to participate voluntarily in various physical activities in the future. Contrary to this situation, students with negative attitudes towards physical education and sports course can decrease the efficiency of the course, not participate in the lesson, may not give importance to the lesson or may have various problems in the process of the lesson (S1lverman and Scrabis 2004).

Disability: It is restricting or cannot fulfill the roles expected from the person depending on the age, gender, social and cultural factors due to insufficiency or disability (Bilir, 1989). Hearing disability is the condition in which the individual's educational performance and social cohesion are adversely affected due to his partially or completely insufficiency to speak, his ability to use the language and his communication difficulties due to his lack of hearing sensitivity. For the occurrence of hearing; the presence of sound, the sound's being within the limits of the frequency and violence that the human ear to be, presence of the organ, ear, which is the organ to perceive sounds, the sound in the ear should pass through the structures in the brain to the hearing center, this sound is needed to be perceived and interpreted correctly in this center (Belgin, 1995). Degrees of Hearing Loss; they are interested in the measurable loss of hearing according to the physiological approach. The classification according to this view accepts children who do not hear sounds at a certain height level as non-hearing children and others as hard hearing. Another classification is the rating made according to the result of hearing tests. As a result of this evaluation can be stated as follows;

- Hearing desibels between 20 - 40 as slight to mild,

- Hearing desibels between $40-70$ as moderate,

- Hearing desibels between $70-92$ as severe,

- Hearing desibels over 92 as considered to be profoundly hearing disabled (Kayaözkatar, 2010).

Hearing problems cause the individual to be introverted, uninterested to his environment and remain unresponsive to events. As the reaction remains unresponsive; socializing problems stands out. Instead of communicating with peers, the individual prefers to communicate with people with disabilities such as himself. Thus, the individual is not able to improve himself and maintain his life in a narrow frame (Polat, 2009).

Sports has a very important function as it provides opportunity by enabling individuals with disabilities to come together with non-disabled individuals for "integration" aimed at special education. In such an environment, the disabled person develops a positive attitude towards himself, observes the problems of other people with disabilities, stimulates creativity, minimizes feelings of loneliness, enlarges his environment and has the chance to live a more meaningful life (Özer, 2001). It can be said that sportive activities improve the psychomotor (balance, force, speed, flexibility, physical fitness) skills of the disabled students in a positive way and make them be constructive, creative and productive. In addition, sportive activities allow the mental development of students with disabilities, learns the phenomenon of win-loss and prepares themselves accordingly(Arac1, 2001). This situation makes it important for the students with disabilities to attend physical education and sports course, to participate in the lesson and to give importance to the course, which results in disabled individuals would tend towards physical education and sports. In other words, the development of positive attitudes towards physical education and sports towards hearing-impaired students led them to turn to sports.

This research was carried out to determine the attitudes and opinions of the hearing impaired students studying at primary, high school and university institutions regarding physical education and sports.

\section{Material and Method}

\subsection{Study Group}

To the study, a total of 136 students (50 females and 86 males) with heairing-impairment, who are participating physical education and sports lesson in provinces of İzmir and Muğla between 2017-2018 education year, voluntarily participated. 


\subsection{Data Collection Tool}

"Physical Education and Sports Attitude Scale" consisting of 12 positive and 12 negative items, a total of 24, which was developed by Demirhan and Altay (2001) was used to measure the attitudes of the students. The lowest score that can be obtained from the scale is 24 points and the highest score is 120 . When the averages are used, the lowest attitude score is 1 and the highest attitude score is 5. Cronbach Alpha reliability coefficient was calculated as 0.93 , and the validity coefficient was calculated as 0.83 (Demirhan, G. and Altay, F. 2001). The scale consists of 24 items and includes two sub-dimensions: positive attitude and negative attitude. The Cronbach's alpha value for negative attitude subscale was 0.787 , and the alpha value for the positive attitude dimension was 0.761 .

\section{Analysis of the Data}

In order to determine whether the data were normally distributed, the skewness and kurtosis values of the attitude scores were examined and it was found that the data were normally distributed as these values were between -1 and +1 (Skewness $=-0,653$, Kurtosis $=0,632$ ). Therefore, parametric tests were used to analyze the data.

In the analysis of the data; frequency, and percentage distributions were used and the relationship between attitude scores was examined by correlation analysis. In the analyzes related to physical education and sport attitude scale scores, the t-test was used to determine the differences according to gender, sporting status, and disability status. In addition, one-way analysis of variance (ANOVA) was used to determine differences according to educational status, branches of sports, and level of income.

\section{Findings}

When the participants were analyzed according to their demographic features, the findings were found.

Table 1. Distribution according to demographic features

\begin{tabular}{|c|c|c|c|}
\hline & & $\mathrm{N}$ & $\%$ \\
\hline \multirow[t]{2}{*}{ Gender } & Male & 86 & 63,2 \\
\hline & Female & 50 & 36,8 \\
\hline \multirow[t]{3}{*}{ Educational Status } & $\begin{array}{l}\text { Primary } \\
\text { School }\end{array}$ & 40 & 29,4 \\
\hline & $\begin{array}{l}\text { High } \\
\text { School }\end{array}$ & 50 & 36,8 \\
\hline & University & 46 & 33,8 \\
\hline \multirow[t]{2}{*}{ Sporting Status } & Yes & 75 & 55,1 \\
\hline & No & 61 & 44,9 \\
\hline \multirow[t]{3}{*}{ Branches of Sports } & $\begin{array}{l}\text { Individual } \\
\text { Sports }\end{array}$ & 51 & 37,5 \\
\hline & $\begin{array}{l}\text { Team } \\
\text { Sports }\end{array}$ & 28 & 20,6 \\
\hline & None & 57 & 41,9 \\
\hline \multirow[t]{3}{*}{ Level of Income } & $500-1000$ & 42 & 30,9 \\
\hline & $1001-2000$ & 46 & 33,8 \\
\hline & 2001- & 48 & 35,3 \\
\hline \multirow[t]{2}{*}{ Disability Status } & Congenital & 52 & 38,2 \\
\hline & Afterward & 84 & 61,8 \\
\hline
\end{tabular}

Table 2. T-Test Results of the Participants' physical education and sports attitude scale scores according to gender

\begin{tabular}{lcccccc}
\hline Gender & $\mathrm{N}$ & Average & $\mathrm{S}$ & Std. D. & $\mathrm{t}$ & $\mathrm{p}$ \\
\hline Male & 86 & 2,9787 & 0,26956 & 134 & 2,361 & 0,02 \\
Female & 50 & 2,8517 & 0,35257 & & & \\
\hline
\end{tabular}

According to the results of t-test, in terms of females and males' physical education and sports attitude scale scores, there was a significant difference between males and females $(\mathrm{t}(134)=2,36, \mathrm{p}<0,05)$ and males showed a more positive attitude than females.

Table 3. ANOVA Results of Physical Education and Sports Attitude Scale Scores According to Education Status

\begin{tabular}{lccccc}
\hline Education Status & $\begin{array}{c}\text { Sum of } \\
\text { Squares }\end{array}$ & df & $\begin{array}{c}\text { Average of } \\
\text { Squares }\end{array}$ & F & $\mathrm{p}$ \\
\hline Inter-Groups & 0,424 & 2 & 0,212 & 2,285 & 0,106 \\
Intra-Groups & 12,353 & 133 & 0,093 & & \\
Total & 12,777 & 135 & & & \\
\hline
\end{tabular}

According to One-way analysis of variance results; no significant difference was found between the scores of physical education and sports attitude scale $(\mathrm{F}(2-133)=2,285, \mathrm{p}>, 05)$. 
Table 4. T-Test Results of the Participants' Physical Education and Sports Attitude Scale Scores According to Sporting Status

\begin{tabular}{lccccccc}
\hline Sporting S. & & $\mathrm{N}$ & Avg. & $\mathrm{S}$ & Std. D. & $\mathrm{t}$ & $\mathrm{p}$ \\
\hline Doer & Yes & 75 & 2,9683 &, 31028 & 134 & 1,535 &, 127 \\
Not-Doer & No & 61 & 2,8873 &, 30088 & & & \\
\hline
\end{tabular}

According to the results of the t-test, no significant difference was found between the scores of physical education and sports attitude scale $(\mathrm{t}(134)=1,535, \mathrm{p}>, 05)$.

Table 5. ANOVA Results of Physical Education and Sports Attitude Scale Scores According to Branches of Sports

\begin{tabular}{cccccc}
\hline $\begin{array}{c}\text { Branches of } \\
\text { Sports }\end{array}$ & $\begin{array}{c}\text { Sum of } \\
\text { Squares }\end{array}$ & df & $\begin{array}{c}\text { Average } \\
\text { of Squares }\end{array}$ & F & $\mathrm{P}$ \\
\hline Inter-Groups & 0,265 & 2 & 0,132 & 1,408 & 0,248 \\
Intra-Groups & 12,512 & 133 & 0,094 & & \\
$\quad$ Total & 12,777 & 135 & & & \\
\hline
\end{tabular}

According to the results of one-way analysis of variance, no significant difference was found between physical education and sports attitude scale scores $(\mathrm{F}(2-133)=1.408, \mathrm{p}>, 05)$.

Table 6. ANOVA Results of Physical Education and Sports Attitude Scale Scores According to Level of Income

\begin{tabular}{lccccc}
\hline Level of Income & $\begin{array}{c}\text { Sum of } \\
\text { Squares }\end{array}$ & df & $\begin{array}{c}\text { Average of } \\
\text { Squares }\end{array}$ & F & P \\
\hline Inter-Groups & 1,126 & 2 & 0,563 & 6,425 & 0,002 \\
Intra-Groups & 11,651 & 133 & 0,088 & & \\
Total & 12,777 & 135 & & & \\
\hline
\end{tabular}

When one-way variance analysis results were analyzed, it was determined that there was a significant difference between the scores of physical education and sports attitude scale according to level of income (F (2-133) $=6,425, \mathrm{p}<$, 05). As a result of Post-Hoc tests to determine in which of these groups the differentiation occurred; it was stated that there was a difference between 500-1000 and 2000, 500-1000 and over 2000; but there was no significant difference between 1000-2000 and over 2000 according to attitude scores.

Table 7. T-Test Results of the Participants' Physical Education and Sports Attitude Scale Scores According to Disability Status

\begin{tabular}{ccccccc}
\hline Disability Status & $\mathrm{N}$ & Average & S & Std. D. & T & p \\
\hline Congenital & 52 & 2,9792 & 0,27323 & 134 & 1,412 & 0,16 \\
Afterward & 84 & 2,9028 & 0,32529 & & & \\
\hline
\end{tabular}

According to the $t$ test results, no significant difference was found between the scores of physical education and sports attitude scale $(\mathrm{t}(134)=1,412, \mathrm{p}>, 05)$.

\section{Discussion and Result}

The aim of this study was to determine the attitudes and opinions of the hearing impaired athletes and non-athletes who study in various educational institutions in İzmir and Muğla about physical education and sports lesson. The secondary aim of the study is to determine whether there is a significant difference or relationship between the levels of attitudes towards physical education and sports course in terms of demographic characteristics. A total of 136 hearing-impaired students, including 86 male and 50 female, participated in the study voluntarily.

When the study findings were examined, it was seen that almost all the information was similar to the general literature information; although the average scores of the students were high, the attitude scores of the male students were higher than the female students ( $\mathrm{p}<0.05$ ). In their study, Çelik and Pulur (2011) found that male students' attitudes towards physical education and sports lesson were generally more positive than girls. In their study, Taşğın and Tekin (2009) found that male students' attitudes towards physical education course were generally higher than girls. According to the study conducted by Koca and Demirhan (2004), attitude scores of males showed a significant difference according to girls' attitude scores. In their study, Smoll and Schutz (1980) found that male students' attitudes towards physical education course were generally more positive than girls. These studies show a similarity to our study. 
No significant difference was found between the attitudes of physical education and sports according to school types (p>, 05). In the study conducted by Çelik and Pulur (2011), the scores of the students do not show a significant difference according to the type of school. As a result of Dalbudak et al. (2016) 's research on visually impaired students; they found that attitudes towards physical education and sports did not differ according to the type of school. Socially, the human is an asset that needs education (Yaşar and Çerçi, 2017). For this reason, even if the type of education or school of hearing-impaired individuals is different; we think that physical education and sports are not different in their attitudes towards physical education and sports and they are individuals who need sports. These studies show a similarity to our study.

There was no significant difference between the scores of physical education and sports attitude scale of the hearing impaired individuals who did sports and did not (p>, 05). Regardless of the disability status, participation in sports activities, movement, and exercise increase the disabled person' desire to live. People with disabilities can solve their loneliness through sports, they share their problems with others, establish friendships, learn to share, learn make common decisions, get discipline, socialize, learn to remain calm, discover and develop their abilities, have positive feelings towards themselves, and love life; which enables individual to carry his life on (Dalbudak, 2012). It can be said that sports activities are important for physical education and sports hearing-impaired students because they enable the disabled students to develop their psychomotor skills in a positive way and make them constructive, creative and productive. For the disabled, physical education and sports attitudes are very important.

According to sports branches, there was no significant difference between physical education and sports attitude scale scores (p>, 05). It is seen that both groups have positive attitudes. Although hearing impaired athletes are in different branches, we can say that their attitudes towards physical education and sports are the same. In a study conducted by Dalbudak et al. (2016), it was seen that visually-impaired individuals' physical education and sports attitudes did not show a significant difference in terms of branches of sports. It is seen that both groups have positive attitudes. The individuals with a hearing disability have the same attitude towards physical education and sports, although the athletes have different branches. Thanks to the sports, hearing-impaired individuals improve the mobility capabilities of the body, enjoy fun and happiness, prevent tension healthily and prevents relaxation, and help them how to develop friendship and good sportsmanship and make their presence felt in society. In this way, the social development of the individual is provided and he thinks positive thoughts about himself and connects to life more closely. Visually impaired athletes who are interested in individual and team sports know their characteristics and they have a positive attitude. Since the study was similar to the study we have done, the finding that will support our study has been reached.

A significant difference was found according to the level of income between 500-1000 and 1000-2000, between 500-1000 and over 2000 ( $\mathrm{p}<, 05)$. We can say that individuals with hearing disabilities have a different level of income and their attitudes towards physical education and sports are different. The fact that the level of income is different shows that the expectations of individuals with hearing impairments against physical education and sports are also different. Since there are no similar studies in our study, there are no findings to support.

There was no significant difference according to disability status (p>, 05). When we look at the common point of hearing disability individuals, whether they have congenital or afterward disability, we can say that their attitudes towards physical education and sports are the same. It is seen that both groups have congenital or afterward disabilities and their expectations from physical education and sports are not different and in the same direction. As individuals with positive attitudes towards physical education and sports are seen to be more hardworking, more productive, happier and more peaceful than other individuals in the society, hearing-impaired individuals can also benefit from physical education and sport activities in their lives and they sparing substantial time on sports activities shows that they display a positive attitude towards physical education and sports. We think that the attitudes towards physical education and sports do not have an effect on the type of disability and that there is no difference between the attitudes of individuals related to physical education and sports whether they are congenitally handicapped or not. As there were no studies similar to our study, there were no supportive findings.

As a result, it has been determined that physical education and sports activities of hearing-impaired individuals will provide important benefits in their future lives, they spare a substantial amount of time for physical education and sports activities, and they have a positive attitude towards physical education and sports.

\section{References}

Aracı, H. (2001), Öğretmen ve Öğrenciler için Okullarda Beden Eğitimi, 3.Baskı, Nobel Yayınevi, 6-7, Ankara.

Belgin, E. (1995) İşitme Engelli Öğrencilerin İlkokul Öğretmenlerine Yaklaşım Prensipleri, Unıcef Türk Temsilciliği, 12, Ankara.

Bilir, Ş. (1989). Engelli Çocuklar ve Eğitimleri, H.Ü. Çocuk Sağlıgı ve Eğitimi Bölümü, 8, Ankara. 
Çelik, Z., \& Pulur, A. (2011) Ortaöğretim Öğrencilerinin Beden Eğitimi ve Spora İlişkin Tutumları, Ulusal Beden Eğitimi ve Spor Öğrt. Kongresi, VAN/YYÜ Eğitim Fakültesi Dergisi Özel Sayıs1, 115-121.

Dalbudak, İ. (2012). 13-15 Yaş Arası Görme Engelli Sporcuların Stres ve Saldırganlık Düzeylerinin İncelenmesi, Ege Üniversitesi, Sağlık Bilimler Enstitüsü, Sporda Psiko-Sosyal Alanlar Anabilim Dalı, Yayımlanmış Yüksek Lisans Tezi, 103-104. İzmir.

Dalbudak, İ., Gürkan, C., A., Yiğit, M., Ş., Kargun, M., Hazar, G., \& Dorak, F. (2016) Investıgatıng Vısually Dısabled Students' Attitudes About Physical Education and Sport, International Journal Of Environmental \& Science Education, 11(6), 9437- 9447.

Demirhan, G., \& Altay, F. (2001). Lise Birinci Sınıf Öğrencilerinin Beden Eğitim ve Spora İlişkin Tutum Ölçeği II. Spor Bilimleri Dergisi, 12(2), 9-20.

Ertürk, S. (1998). Eğitimde Program Geliştirme. Ankara: Meteksan Matbaacılık.

Güllü, M., \& Güçlü, M. (2009). Ortaöğretim Öğrencileri İçin Beden Eğitimi Dersi Tutum Ölçeği Geliştirilmesi. Niğde Üniversitesi Beden Eğitimi ve Spor Bilimleri Dergisi, C.3, S.2, S.139-140.

Kaya, O. E. (2010). 18-25 Yaş Arası İşitme Engelli Sporcuların Stres ve Saldırganlık Seviyelerinin İncelenmesi, Yayınlanmış Yüksek Lisans Tezi, Sosyal Bilimler Enst. Beden Eğitimi ve Spor Öğretmenliği Anabilim Dalı, Kayseri, S.3-10.

Koca, C., \& Demirhan, G. (2004). An Examination Of High School Students' Attitudes Toward Physical Education With Regard To Sex And Sport Participation. Percept Motor Skill, 98, 754-758.

Özer, D. (2001) Engelliler İçin Beden Eğitimi ve Spor, Nobel Yayın Dağııım, Ankara, 1-89.

Polat E. (2009). İşitme Engelli Güreşçilerle Sağlıklı Güreşçilerin Dinamik Dengelerinin Karşılaştırılması, Dumlupınar Üniversitesi, Sosyal Bilimler Enstitüsü, Beden Eğitimi ve Spor Anabilim Dalı, Yüksek Lisans Tezi, Kütahya.

Safrit, M. J., \& Wood, T. M. (1995). Introduction To Measurement in Physical Education and Excercice Science. (3rd Ed.) St. Louis, MO: Mosby.

Silverman, S., \& Scrabis K. A. A. (2004). Review of research on instructional theory in physical education 2002-2003, International Journal of Physical Education, 41(1), 4-12.

Smoll, F. L., \& Schutz, R. V. (1980). Children's Attitudes Towards Physical Activity: a longitudial analysis. J Sport Psychol, (2), 137-147.

Taşğın, Ö., \& Tekin, M. (2009). Çeşitli Değişkenlere Göre İlköğretim Ve Orta Öğretim Kurumlarında Öğrenim Gören Öğrencilerin Beden Eğitimi Ve Spor Dersine İlişkin Tutum ve Görüşleri. Kastamonu Eğitim Dergisi, 17(2), 457-466.

Tezbaşaran, A. (1997). Likert tipi ölçek hazırlama kılavuzu. Ankara: Türk Psikologlar Derneği.

Yaşar, Ö., \& Çerçi, N. K. Artvin Yusufeli İlçesi Örnekleminde Doğum. Sosyolojik Düşün, 2(1), 31-44.

\section{Copyrights}

Copyright for this article is retained by the author(s), with first publication rights granted to the journal.

This is an open-access article distributed under the terms and conditions of the Creative Commons Attribution license which permits unrestricted use, distribution, and reproduction in any medium, provided the original work is properly cited. 